Hasanuddin Law Review is licensed under a Creative Commons Attribution 4.0 International License, which permits unrestricted use, distribution, and reproduction in any medium, provided the original work is properly cited.

\title{
Legal Policy of Water Resources Management by Local Governments: A Review of Right to Water in Indonesia
}

\author{
Nadia Astriani \\ Faculty of Law Padjadjaran University \\ Jl. Dipati Ukur No. 35, Bandung, West Java 40132, Indonesia \\ Tel./Fax:+6222-4220696E-mail: nadia.astriani@unpad.ac.id
}

Submitted: Apr 16, 2016; Reviewed: Jul 4, 2016; Accepted: Jul 23, 2016

\begin{abstract}
This study is based by the cancellation of Act No. 7 of 2004 on Water Resources by the Indonesian Constitutional Court. Over the past 10 years, the law is the basis for the water resources management in Indonesia. The cancellation of the law would provide great impact for water resources management policy, especially with regard to the provision of right to water. Hence, this study aimed to determine the legal status of Right to Water provided by the local government after the cancellation of Act No. 7 of 2014 on Water Resources. The object of this normative study includes legal principles and systematic. This is due to the focus of this study is the meaning of the right principle to ruled state in the context of realizing the peoples' prosperity and the position of Water Resources Act as the basis for the issuance of Government Regulation and Right to Water. The results of study indicate that in order to provide legal certainty for permit holder for Right to Use Water and Right to Commercialize Water, the ministry has issued various ministerial regulations, although the nature of these regulations only fills a legal vacuum. In the case of permit to Use of Water Resources, all permits for use of water resources that use surface water issued before the decision of Constitutional Court No. 85/PUU-XI/2013 are still valid. To permit referred to it, evaluation is conducted based on 6 (six) the principles of water resources management. Request new permit are in the process or for renewal of permit to use water resources that use surface water, processed as 6 (six) principles of water resources management. Although, in order to ensure legal certainty, the government should immediately issues the Act in Lieu of Water Resources Management which will be the basis for water resources management in Indonesia.
\end{abstract}

Keywords: Legal Policy, Permit; Right to Water; Water Resources

DOI: http://dx.doi.org/10.20956/halrev.v1n2.309

\section{INTRODUCTION}

Water is an important part for human life. Therefore, the right to water is a human right and one of the constitutional rights. The availability of water in the world is always constant while the demand for water continues to increase each year, causing scarcity, at this scarcity stage, the principle of justice in water management becomes very important. The government must guarantee the fulfillment of the right to water. ${ }^{1}$

The Indonesian Constitutional Court (MK) on 18 February 2015 by Decision No. 85/PUU-XI/2013 has canceled the enactment

\footnotetext{
I Gusti Ngurah Parikesit Widiatedja. (2015). "Protecting Indigenous Peoples through Right to Natural Resources: Lesson from the Existence of Navajo Tribe in the United States." Hasanuddin Law Review, 1(3), 307315. doi: http://dx.doi.org/10.20956/halrev.v1n3.111
} 
of Act No. 7 of 2004 on Water Resources. This decision is the culmination of 2 (two) earlier court's decision regarding the Water Resources Act, in which previously the court has twice decide material test for the Water Resources Act. Before, the court has issued Decision No. 058-059-060-063/PUUII/2004 and No. 008/PUU-III/2005 related to the material test of the Water Resources Act.

Before canceled, Article 6 - 10 of the Water Resources Act considered as justification for water commercialization, this is because the ruling of State determined on the Right to Water which consists of Right to Use Water and Right to Commercialize Water as the basis for giving permit by the central or local government. The issuance of Government Regulation No. 16 of 2005 on the Development of Water Supply System (it is also called as SPAM - Sistem Penyediaan Air Minum), which in Article 1 Clause 9 states "the organizing of SPAM development is the state/local enterprises, cooperatives, private enterprises, or groups of people". This regulation strengthens the transfer of governments' responsibility to the private sector. In fact, in Article 40 Paragraph (2) of the Water Resources Act has been stated that the development of SPAM is the responsibility of either central or local governments.

As background above, this study was conducted to analyze the legal implications due to the cancellation of Act No. 7 of 2004 on Water Resources to permit for Right to Commercialize Water provided by local government. As this study aimed to determine the legal status of permit the Right to Commercialize Water provided by the local government after the cancellation of Act No. 7 of 2014 on Water Resources.

\section{METHOD}

This study is a legal research that using a normative approach, the legal research that focuses on secondary data. ${ }^{2}$ Primary data derived from field studies, used to clarify, supplement and verify secondary data. Norma studied in this research is the legislation in the field of water resources management and the decision of the Constitutional Court judges. The object of this normative study includes the principles and systematic of law.

The data collection is done by literature review and information gathering using interviews with resource persons determined purposively (judgmental). Data and information obtained, analyzed by juridicalqualitative, whether obtained through library research and interviews. Qualitative analysis was conducted on data and information that is determined based on the principles and norms of the legislation or is commonly accepted, and based on the values that live in the community. Qualitative analysis was conducted using legal interpretation method, law analogy and construction.

\section{ANALYSIS AND DISCUSSION}

Water resources management is an effort of planning, implementing, monitoring and evaluating the implementation of water resources conservation, water resources utilization and water damage control. Water resources utilization is done through the Right

\footnotetext{
Ronny Hanitidjo Soemitro. (1990). Metodologi Penelitian Hukum dan Juritmetri. Jakarta: Ghalia Indonesia, p. 11.
} 
to Water.

Right to Water is a right to obtain and use or commercialize water for various purposes. It is divided into 2 (two): First, the Right to Use Water (hereinafter abbreviated HGPA or called Hak Guna Pakai Air) is the right to obtain and use water; Second, the Right to Commercialize Water (hereinafter abbreviated HGUA or called Hak Gua Usaha Air) is the right to obtain and commercialize water. Both of these rights can be obtained in two ways, i.e. without permit and with permit.

Post-cancellation of Act No. 7 of 2004 on Water Resources, legally all legislation as the law implementer to be "null and void". The re-enactment of Act No. 11 of 1974 on the Watering in principle can still be said to be relevant but do not necessarily solve the problems of water resources management, especially considering the substance of the legislation has been progressing at this time. ${ }^{3}$

The implications of Constitutional Court's decision are Government Regulation, Presidential Regulation, Presidential Decree, and Ministerial Regulation as derivatives of the Water Resources Act does not apply, resulting in things below do not have a legal basis:

a) Public-Private Partnership (PPP), the Service-Cost of Water Resources Organizer or Biaya Jasa Pengelola SDA (BJPSDA), the coordinating institution (A Council of Water Resources, TKPSDA WS);

b) The division of the basin (WSWilayah Sungai) as the operational

3 Ahmad Redi. (2014). Hukum Sumber Daya Alam dalam Sektor Kehutanan. Jakarta: Sinar Grafika, p. 42 basis for integrated and sustainable water resources management;

c) The existence of water resources management organization (WS Hall, BPPSPAM);

d) The existence of patterns and plans of the basin (WS) and maintenance operations;

e) Management of the dam; and

f) The existence of Development Support Agency of Water Supply System.

The Constitutional Court's Decision No. 85/PUU-XI/2013 give limits water resources management with 6 (six) advanced principles as follows:

1) Every commercialization for water should not interfere, override, let alone negate the people's right to water as earth, water, and natural contained therein other than to be ruled by the State, as well as the designation is for the greater prosperity of the people;

2) The State shall fulfill people's right to water, as considered above, access to water is one of the human rights of its own then the first paragraph of Article 28I (4) of the Constitution 1945 determines, "Protection, improvement, reinforcement, and fulfilment of human rights shall be the responsibility of the state, particularly the government.";

3) Considers the conservation of the environment, because as one of human rights, Article $28 \mathrm{H}$ paragraph (1) the Constitution 1945 stipulates: "Everyone shall be entitled to be prosperous, reside, and obtain proper and sound environment and medical services."; 
4) As an important branch of production and dominate the life of a lot to be ruled by the State (vide Article 33 paragraph (2) of the Constitution 1945) and water in accordance with Article 33 paragraph (3) of the Constitution 1945 should be ruled or controlled by the State and used for the greatest prosperity of the people, so supervision and control by the state over the water is absolute;

5) As a continuation of the rights of rule by the State and because water is something very dominate the life of a lot of the people, so the main priority given to water utilization are the State Owned Enterprises or Regional-Owned Enterprises; and

6) If, after all of the restrictions have been met and that there is still water availability, the Government is still possible to grant permit to private companies to do the commercialization on the water with certain conditions and tight.

In regard to the permit to use water resources provided by the government, the Ministry of Public Works and Public Housing issued Circular of the Minister of Public Works and Public Housing No. 04/ $\mathrm{SE} / \mathrm{M} / 2015$ on the permit for Use of Water Resources and Cooperation Contract of Public-Private Partnership in the Piping Water Supply System after the Constitutional Court's Decision Number: 85/PUU-X/2013. In this case, permit to use water resources: a) All permit to use water resources that use surface water issued before the Constitutional Court's Decision No. 85/PUU-XI/2013 is still valid; b) To permit referred to in letter (a) evaluation is done based on 6 (six) principles of water resources management as referred to in point 1 ; c) Request new permit are in the process or request for renewal of the permit to use water resources that use surface water, processed based on 6 (six) principles of water resources management as referred to in point 1; and d) Evaluations referred to in point (b) conducted by the agency as permit giver.

In order to fill the legal vacuum, various efforts made by the government to plan alternative arrangements. Act No. 12 of 2011 concerning the establishment of legislation, legislation that is in accordance with the hierarchy of legislation includes:

a) The Constitution of the Republic of Indonesia 1945;

b) The Decree of People's Consultative Assembly;

c) Law/Government Regulation in Lieu of Law;

d) Government Regulations;

e) Presidential Decree;

f) Provincial Regulation; and

g) Regency/Municipal Regulation

Based on the hierarchy will apply the principle of hierarchy as conformity of regulatory material, wherein the regulatory material must be based on the higher material arrangement, so it is not given the opportunity of a regulation that has a lower hierarchy against the rules above.

In legislation system, government regulations and presidential decree cannot be compiled without the rules above (legislation), but in a presidential decree contains a provision that a Presidential Decree can be formed in order to carry out government 
Table 1. The Ministerial Regulation Relating to the Water Resources

\begin{tabular}{|c|c|c|}
\hline No. & Ministerial Regulation & Status \\
\hline 1 & Ministerial Regulation on Criteria and Zoning River & Permen PUPR No. 04/PRT/M/2015 \\
\hline 2 & $\begin{array}{l}\text { Ministerial Regulation on the Exploitation and Water } \\
\text { Resources Management and Irrigation }\end{array}$ & Permen PUPR No. 06/PRT/M/2015 \\
\hline 3 & Ministerial Regulation on Safety Beach & Permen PUPR No. 07/PRT/M/2015 \\
\hline 4 & $\begin{array}{l}\text { Ministerial Regulation on of Irrigation Line Border } \\
\text { Determination }\end{array}$ & Permen PUPR No. 08/PRT/M/2015 \\
\hline 5 & Ministerial Regulation on the Use of Natural Resources & Permen PUPR No. 09/PRT/M/2015 \\
\hline 6 & $\begin{array}{l}\text { Ministerial Regulation on Plan and Technical Plan of } \\
\text { Water Arrangement and Irrigation System }\end{array}$ & Permen PUPR No. 10/PRT/M/2015 \\
\hline 7 & $\begin{array}{l}\text { Ministerial Regulation on Exploitation and Reclamation } \\
\text { System Maintenance of Tidal Swamp }\end{array}$ & Permen PUPR No. 11/PRT/M/2015 \\
\hline 8 & $\begin{array}{l}\text { Ministerial Regulation on Exploitation and Irrigation } \\
\text { System Maintenance }\end{array}$ & Permen PUPR No. 12/PRT/M/2015 \\
\hline 9 & $\begin{array}{l}\text { Ministerial Regulation on Disaster Emergency Response } \\
\text { due to Water Damage Power }\end{array}$ & Permen PUPR No. 13/PRT/M/2015 \\
\hline 10 & $\begin{array}{l}\text { Ministerial Regulation on Criteria and Status } \\
\text { Determination of Irrigation Area }\end{array}$ & Permen PUPR No. 14/PRT/M/2015 \\
\hline 11 & $\begin{array}{l}\text { Ministerial Regulation on Exploitation and Irrigation } \\
\text { System Maintenance of Lebak Swamp }\end{array}$ & Permen PUPR No. 16/PRT/M/2015 \\
\hline 12 & Ministerial Regulation on Irrigation Commission & Permen PUPR No. 17/PRT/M/2015 \\
\hline 13 & $\begin{array}{l}\text { Ministerial Regulation on Exploitation Fee and Watering } \\
\text { Building Maintenance }\end{array}$ & Permen PUPR No. 18/PRT/M/2015 \\
\hline 14 & $\begin{array}{l}\text { Ministerial Regulation on Exploitation and Irrigation } \\
\text { System Maintenance of Farming }\end{array}$ & Permen PUPR No. 21/PRT/M/2015 \\
\hline 15 & Ministerial Regulation on Irrigation Asset Management & Permen PUPR No. 23/PRT/M/2015 \\
\hline 16 & $\begin{array}{l}\text { Ministerial Regulation on Transfer of River Flow and/or } \\
\text { Ex-river path utilization }\end{array}$ & Permen PUPR No. 26/PRT/M/2015 \\
\hline 17 & Ministerial Regulation on Dams & Permen PUPR No. 27/PRT/M/2015 \\
\hline 18 & $\begin{array}{l}\text { Ministerial Regulation on Determination of the River } \\
\text { Border Line and Lake Border Line }\end{array}$ & Permen PUPR No. 28/PRT/M/2015 \\
\hline 19 & Ministerial Regulation on Swamp & Permen PUPR No. 29/PRT/M/2015 \\
\hline 20 & $\begin{array}{l}\text { Ministerial Regulation on Development and Irrigation } \\
\text { Systems Management }\end{array}$ & Permen PUPR No. 30/PRT/M/2015 \\
\hline 21 & $\begin{array}{l}\text { Ministerial Regulation on Permit to Use Water and/or } \\
\text { Source of Water }\end{array}$ & Permen PUPR No. 37/PRT/M/2015 \\
\hline
\end{tabular}

Source: Ministry of Public Works and People Housing, 2015.

power, but still in a sense, not contradict with higher regulations. Currently, the Ministry of Public Works and People Housing is proposing a draft presidential decree on Water Resources, while drafting a new Water Resources Act. ${ }^{4}$

One alternative to fill the legal vacuum before re-enactment of Water Resources Act is drafting regulation of the minister in charge of water resources. In its legal form

4 Interview with Head of Law Department, Secretariat General of Water Resources, Directorate General of Water Resources the Ministry of Public Works and People Housing, on 12 August 2015 the ministerial regulation is likely drafted based on Article 8 of Act No. 11 of 2012 that the ministerial regulation recognized and have binding legal force throughout ordered by legislation that is higher or established by the authority. ${ }^{5}$ In forming a ministerial regulation which is based on authority, in principle, must not contradict with the laws and regulations on it, but when the public interest and prevent disorder in the people

Syaiful Bahri Ruray. (2012). Tanggung Jawab Hukum Pemerintahan Daerah dalam Pengelolaan dan Pelestarian Fungsi Lingkungan Hidup. Bandung: Penerbit Alumni, p. 23. 
due to legal vacuum, sometimes a ministerial regulation to be a solution, but its position is not strong may at any time be canceled when in contradict with the implementation of legislation either vertically or horizontally.

Several ministerial regulations issued to fill the legal vacuum after the issuance of the Constitutional Court's decision as shown in Table 1 above. The regulation of the Minister of Public Works and Public Housing No. 37/PRT/M/2015 intended as a reference to the requester and permit giver in the process of permitting the use of water and/or water source for business activities. In addition ministerial regulation aims to realize orderly organization of the permit to use water and/or water source for business activities.

Article 3 of the Regulation of the Minister of Public Works and Public Housing No. 37/PRT/M/2015 states:

(1) In this ministerial regulation, permits the use of water and/or water source for business activities as referred to in Article 2, the next in this ministerial regulation so called permit the use of water resources should be owned by government agencies, legal entities, social agencies, or individuals the use of water, and water resources. Permit referred to in paragraph (1), is given in order of priority:

a. Fulfillment of basic needs of everyday life that use large amounts at one point making;

b. People farming outside of the existing irrigation system;

c. The use of water resources to meet the basic needs of everyday through business activities of drinking water supply systems;

d. Activities not business; and

e. The use of water resources for other business activities.
(2) Permit for use of water resources for surface water as referred to in paragraph (1) letter $a$, may be given to the type of activity:

a. Fulfillment of irrigation water by farmers or groups of farmers to the community agricultural outside the existing irrigation system;

b. Providing clean water or drinking water by government agencies, legal entities, social agencies, or individuals who use water resources;

c. The se of water resources for power generation;

d. The utilization of water resources space for construction activities include bridges, dams, weirs, dikes, docks, network or water pipes, electrical wiring and water resources infrastructure;

e. The use of riverbanks and/or riparian for construction activities include bridges, piers, network or stretch of water pipes, electrical wiring and water resources infrastructure;

f. The utilization of riparian and lake body for construction activities include a dock, network or water pipes, electrical wiring and water resources infrastructure;

g. The use of water resources to the activities of plantation, farm, and aquaculture;

h. Tours or water sports;

i. The utilization of water resources for research, development and education;

j. The use of water resources for industry; or

k. Water use for exploration and exploitation of mining commodities.

(3) Permit for use of water resources for sea water on land referred to in paragraph (1) letter $b$, given, among others, for the use of water resources for farming, drinking water, and engine cooling system, and the fulfillment of irrigation water for the agricultural community outside of the existing irrigation system. 
(4) Permit for use of water resources as referred to in paragraph (2) and paragraph (3), is given by:

a. Minister to obtain and use the water resources in the trans-provincial river area, trans-national river area, and nationally strategic river area;

b. Governor to obtain and use the water resources in the trans-district/ municipality river area; or

c. Regent/mayor to obtain and use the water resources in one district/ municipality area.

Although the ministry has issued various ministerial regulations, the nature of these regulations only fills a legal vacuum. The government should prioritize new laws regarding water resources, to provide a stronger legal basis for the use of water resources. Because arrangements in Act No. 11 of 1974 has been less suited to the development of water resource management in Indonesia.

\section{CONCLUSION}

To provide legal certainty for permit to use water resources, the ministry has issued various ministerial regulations, though the nature of these regulations only fills a legal vacuum. In the case of permit to use water resources: a) All permit use of water resources that use surface water issued before the Constitutional Court's Decision No. 85/PUU-XI/2013 is still valid; b) To permit referred to in letter $a$ evaluation is done based on 6 (six) principle of water resources management; c) Request new permit are in the process or for renewal of the permit to use water resources that use surface water, processed based on 6 (six) principles of water resources management; and d) Evaluation was done by the agency issuing the permit.
Water is a human right as well as one of the constitutional rights. Therefore, water resource management need to be regulated immediately. The government should prioritize new laws regarding water resources, to provide a stronger legal basis for the use of water resources. Due to the arrangement in Act No. 11 of 1974 has been less suited to the development of water resource management in Indonesia. While waiting for the new legislation, the government could immediately ratify the Presidential Decree on Water Resources that will provide a stronger legal basis for water resources management.

\section{REFERENCES}

Ahmad Redi. (2014). Hukum Sumber Daya Alam dalam Sektor Kehutanan. Jakarta: Sinar Grafika.

I Gusti Ngurah Parikesit Widiatedja. (2015). "Protecting Indigenous Peoples through Right to Natural Resources: Lesson from the Existence of Navajo Tribe in the United States." Hasanuddin Law Review, 1(3), 307-315. doi: http:// dx.doi.org/10.20956/halrev.v1n3.111

Ronny Hanitidjo Soemitro. (1990). Metodologi Penelitian Hukum dan Juritmetri. Jakarta: Ghalia Indonesia.

Syaiful Bahri Ruray. (2012). Tanggung Jawab Hukum Pemerintahan Daerah dalam Pengelolaan dan Pelestarian Fungsi Lingkungan Hidup. Bandung: Penerbit Alumni.

The 1945 Constitution of the Republic of Indonesia.

The Constitutional Court's Decision No. 85/ PUU-IX/2013 
The Government Regulation of the Republic of Indonesia No.69 of 2014 on the Right to Water

The Regulation of the Ministry of Public Works and People Housing the Republic of Indonesia No.37/PRT/M/2015 on
Permit the Use of Water and/or Water Source

The Regulation of the Ministry of Public Works and People Housing the Republic of Indonesia No. 09/Prt/M/2015 on the Use of Water Resources. 